\title{
MODUS KALIMAT PERINTAH DAN LARANGAN \\ DALAM “ASBAB WURUD AL-HADITS” KARYA IMAM SUYUTHI KAJIAN PRAGMATIK
}

\author{
Ahmad Jazuli ${ }^{1,2}$ \\ ${ }^{1}$ Program Studi Sastra Arab Fakultas Ilmu Budaya \\ Universitas Sebelas Maret Surakarta \\ 2Email: ahmadjazuli@staff.uns.ac.id
}

\begin{abstract}
This article aims to explain the commands and prohibitions of the prophet Muhammad in hadits by using Searle's speech act theory. The purpose of this study focused to describe the commands and prohibitions of the prophet Muhammad in seen from sentence mode. Results of this study indicate that there are several characteristics of the use of the phrase mode commands and prohibitions of the Prophet Muhammad such us declarative sentences mode with verb sentence form and noun sentence form; Imperative sentences mode with fi 'lul-amri form, ismu fi "lil-amri form, dan la an-nahiyah form; and the interrogative sentences mode with using " "iا" an".
\end{abstract}

Keywords: Mode of speech, commands and prohibitions, pragmatics, Al-Imam AsSuyuti.

$$
\begin{aligned}
& \text { ملخّص } \\
& \text { هذه المقالة تبحث عن أوامر النبي و نواهيه في الحديث باستعمال فعل الكلام بمنهج سيرلي. ركز هذا البحث على } \\
& \text { وصف أوامر النبي و نواهيه في شكل الجملة. النتيجة من هذا البحث هي أن هناك العديد من الحصصائص }
\end{aligned}
$$

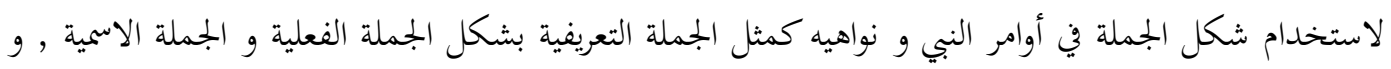

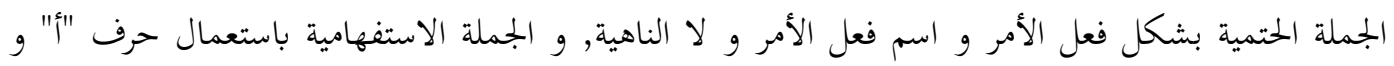

$$
\begin{aligned}
& \text { "ما" } \\
& \text { الكلمات المفتاحية: جهية الكلام، الأمر والنهي، التداولية، الإمام السيوطي. }
\end{aligned}
$$

\section{A. Pendahuluan}

Komunikasi merupakan kegiatan yang sangat penting dalam kehidupan manusia sebagai makhluk sosial. Untuk berkomunikasi, dibutuhkan alat berupa bahasa untuk menyampaikan keinginan, harapan, perasaan, perintah dan sebagainya. Untuk mengetahui pesan atau maksud dalam bahasa dibutuhkan ilmu pragmatik. Ilmu pragmatik adalah studi tentang maksud penutur bahasa yang dihubungkan dengan konteks (Yule, 2006:3). Keinginan, harapan, perasaan, perintah dan larangan merupakan bagian dari ilmu pragmatik yang disebut tindak tutur, yaitu tindakan-tindakan yang ditampilkan lewat tuturan (Yule, 2006:82). Dari beberapa jenis tindak tutur, tindak tutur direktif merupakan tindak tutur yang sering digunakan dalam berkomunikasi. Tindak tutur direktif adalah tindak tutur yang digunakan 
penutur untuk mengekspresikan maksud penutur yang dijadikan alasan bagi petutur untuk bertindak (Bach dan Harnish, 1979:47). Tindak tutur direktif mempunyai beberapa maksud, yaitu perintah, larangan, nasehat, permohonan, berdoa, dan lain-lain.

Salah satu bahasa yang banyak dipelajari adalah bahasa Arab, karena banyaknya kegiatan yang bersinggungan dengan bahasa tersebut, terutama kegiatan umat Islam. Banyak kegiatan ibadah yang mengharuskan pelaksananya untuk memakai bahasa Arab, contohnya ketika melakukan shalat, berdo'a, haji dan sebagainya. Selain itu, bahasa Arab juga merupakan bahasa al-Qur'an dan Hadis yang menjadi pedoman umat Islam. Hal itu membuat pemeluk agama Islam banyak yang belajar bahasa Arab. Oleh karena itu, penting melakukan penelitian tentang bahasa Arab.

(1) Al-Qur'an merupakan firman Allah yang diwahyukan kepada Nabi Muhammad sebagai utusan Allah, sedangkan Hadis adalah perkataan, perbuatan, dan ketetapan Nabi Muhammad sebagai utusan Allah yang membawa ajaran Islam untuk disampaikan kepada manusia. Penelitian ini difokuskan pada Hadis yang merupakan bentuk komunikasi antar manusia, yaitu komunikasi Nabi Muhammad dengan umatnya. Hadis dibagi menjadi tiga sesuai bentuknya, yaitu hadis qauliy yang berupa tuturan, hadis fi'liy yang berupa perbuatan, dan hadis taqririy yang berupa

(2) ketetapan. Diantara ketiga bentuk hadis tersebut, hadis qauliy yang berupa tuturan Nabi Muhammad merupakan hadis yang mempunyai kedudukan paling kuat daripada bentuk hadis lainnya. Tuturan dalam hadis itu berisi ajaran yang sebagian besar berbentuk tindak tutur Direktif yang berupa nasehat, permintaan, doa, perintah, dan larangan. Karena penggunaan tindak tutur direktif banyak digunakan dalam hadis, maka menarik untuk diteliti. Penelitian akan difokuskan lagi pada tindak tutur direktif yang berupa perintah dan larangan karena dua tindak tutur tersebut sangat dominan dalam hadis.
Agar perintah dan larangan yang disampaikan itu diterima dengan baik, tentunya Nabi Muhammad menggunakan bentuk dan strategi tertentu dalam tuturannya yang patut untuk diketahui. Kesuksesan strategi tersebut sudah terbukti dengan menyebarnya Islam ke seluruh dunia. Hal itulah yang membuat penelitian tentang hadis dari segi tindak tutur yang berupa perintah dan larangan menarik untuk dilakukan, sehingga dapat diketahui karakteristik tuturan Nabi Muhammad.

Dalam Hadis, banyak tuturan yang mengandung perintah dan larangan dengan berbagai variasi cara penyampaian, sehingga ditemukan berbagai modus tindak tutur perintah dan larangan. Contoh tuturan dalam Hadis yang mengandung perintah dan larangan adalah sebagai berikut.

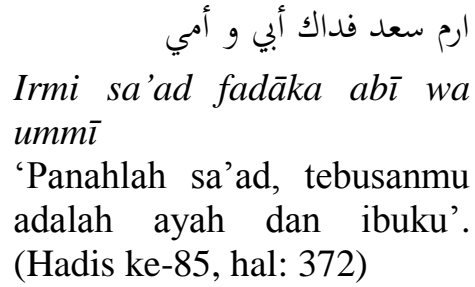

Konteks: tuturan Rasulullah kepada sa'ad ketika melihat ada seorang laki-laki musyrik yang membakar amarah orang Islam dalam perang Uhud.

$$
\text { اللحد لنا و الشقّ لغيرنا }
$$

Al-lahdu lanā wasy-syaqqu ligairinā

'Lahad untuk kita dan syaq untuk selain kita'. (Hadis ke24, hal: 194)

Konteks: tuturan Rasulullah kepada para sahabatnya ketika akan menguburkan seseorang yang baru saja masuk Islam. 


$$
\begin{aligned}
& \text { لا بتمعوا بين الرطب و البسر و بين } \\
& \text { الزبيب و التمر نبيذا }
\end{aligned}
$$

Lā tajma' $\bar{u}$ bainar-ruțabi wal-busri wa bainaz-zabībi wat-tamri nabïzan

'Janganlah

kalian mengumpulkan antara kurma matang dengan kurma yang belum matang dan antara anggur kering dengan kurma kering sebagai minuman'. (Hadis ke-50, hal: 276)

Konteks: tuturan nabi kepada orang-orang yang sedang bersamanya karena ada seorang laki-laki yang mabuk karena minum campuran kurma dan anggur.

Pada contoh (1), tuturan tersebut dituturkan oleh Nabi Muhammad kepada Sa'ad bin Abi Waqas. Tuturan tersebut adalah tuturan yang berbentuk kalimat imperatif yang ditandai oleh fi'il Amr 'irmi' yang bermaksud memerintahkan Sa'ad untuk memanah laki-laki musyrik yang sedang membakar amarah muslimin. Adapun contoh (2), dituturkan oleh Nabi Muhammad kepada para sahabat yang akan mengubur orang yang baru masuk Islam. Tuturan tersebut berbentuk kalimat deklaratif yang bermaksud perintah untuk membuatkan lahad untuk mengubur mayat orang yang baru masuk Islam. Pada contoh (3), tuturan tersebut dituturkan kepada orang-orang yang sedang bersamanya. Tuturan itu berbentuk kalimat imperatif yang ditandai dengan lā an-nāhiyah lā tajma' $\bar{u}$ yang bermaksud larangan untuk mencampur kurma matang dengan kurma yang belum matang dan mencampur anggur kering dengan kurma kering.

Pada contoh-contoh di atas, dapat dilihat bahwa penyampaian perintah dan larangan tidak hanya menggunakan bentuk kalimat imperatif, namun juga dapat menggunakan kalimat deklaratif. Perintah dan larangan juga tidak hanya disampaikan dengan tindak tutur langsung, tetapi bisa juga disampaikan dengan tindak tutur tidak langsung. Oleh karena itu, penelitian ini penting untuk mengetahui modus yang dipakai dalam penyampaian perintah dan larangan dalam hadis. Objek kajian pada penelitian ini adalah buku ang berjudul Asbabul-Wurud Al-Hadis karya Imam Suyuthi. Buku ini memiliki beberapa kelebihan dibanding kitab-kitab hadis yang lain, yaitu praktis, disertai dengan konteks hadis, klasifikasinya berdasarkan ilmu fiqih sehingga lebih aplikatif, kompilasi dari banyak kitab hadis, dan dapat mewakili hadis-hadis dalam kitab hadis lain. Karena kelebihan itulah, kitab ini dijadikan objek kajian dalam penelitian ini.

\section{B. Teori dan Metode Penelitian}

Penelitian ini menggunakan teori tindak tutur Searle dalam kajian pragmatik. Pragmatik adalah kajian tentang hubungan bahasa dengan konteks yang menjadi dasar atas pemahaman bahasa (Levinson, 1983). Hal itu juga senada dengan pendapat Yule (2006:3) yang menyatakan bahwa pragmatik adalah studi tentang maksud penutur bahasa yang dihubungkan dengan konteks. Wijana (1996:1) menyatakan bahwa pragmatik merupakan cabang ilmu bahasa yang mempelajari eksternal bahasa dalam penggunaannya sebagai alat komunikasi. Pragmatik juga mengkaji makna yang berbeda dengan makna yang dikaji dalam semantik. Makna dalam kajian pragmatik adalah makna ujaran yang terdapat pada eksternal bahasa, sedangkan makna dalam kajian semantik adalah makna kalimat yang terdapat pada internal bahasa (Purwo, 1990:16).

Persoalan tindak tutur merupakan salah satu persoalan utama dalam pragmatik. Dalam penggunaannya, Searle dalam parker (1986:17) menyebutkan bahwa tindak tutur dapat dilakukan secara langsung maupun tidak langsung. Tuturan 'Ambilkan buku saya!' menunjukkan tindak tutur ilokusi yaitu meminta secara langsung. Hal itu berbeda dengan tuturan هل تستطيع أن تحمل كتابي؟ 'Bisakah anda membawakan buku saya?' 
yang merupakan bentuk tindak tutur ilokusi meminta secara tidak langsung.

Tindak tutur langsung dapat ditandai dari wujud formal sintaksisnya. Tindak tutur langsung adalah tuturan yang sesuai dengan modus kalimatnya, misalnya kalimat tanya digunakan untuk bertanya, kalimat deklaratif digunakan untuk memberitahukan, sedangkan kalimat perintah digunakan untuk menyuruh, mengajak, atau memohon untuk melakukan sesuatu, contohnya kalimat perintah 'Ambilkan tas saya', kalimat deklaratif كنت أستاذا هنا 'aku ماذا تعمل؟ dosen di sini', dan kalimat tanya 'Apa yang kamu lakukan?'. Sedangkan kalimat tidak langsung adalah tuturan yang berbeda dengan modus kalimatnya, misalnya kalimat tanya digunakan untuk menyuruh, kalimat deklaratif digunakan untuk menawarkan, dan sebagainya. Tindak tutur tidak langsung ini bisa mengakibatkan respon yang beragam tergantung dari konteksnya. Sebagai contoh, tuturan seorang kakak yang lagi belajar kepada adiknya yang bermain bersama teman-temannya sambil berteriak-teriak هل تسنطيع أن تسكت 'apakah kamu bisa diam?'. Tuturan tersebut merupakan kalimat tanya yang digunakan untuk menyuruh.

Berdasarkan fungsinya, Searle (dalam Rahardi, 2005:36) menggolongkan tindak tutur ke dalam lima macam bentuk tuturan yang masing-masing memiliki fungsi komunikatif, yaitu tindak tutur asertif, tindak tutur direktif, tindak tutur ekspresif, tindak tutur komisif, dan tindak tutur deklarasi. Penjelasan kelima macam bentuk tuturan yang menunjukkan fungsi itu dapat dirangkum sebagai berikut:

1. Asertif, yakni bentuk tuturan yang mengikat penutur pada kebenaran proposisi yang diungkapkan, misalnya menyatakan (stating), menyarankan (suggesting), menbual (boasting), mengeluh (complaining), dan mengklaim (claiming).

2. Direktif, yakni bentuk tuturan yang dimaksudkan penuturannya untuk membuat pengaruh agar si mitra tutur melakukan tindakan, misalnya, memesan (orderin), memerintah (commanding), memohon (requesting), menasehati (advising), dan merekomendasi (recommending).

3. Ekspresif, adalah bentuk tuturan yang berfungsi untuk menyatakan atau menunjukkan sikap psikologis penutur terhadap suatu keadaan, misalnya berterima kasih (thanking), memberi selamat (congratulating), meminta maaf (pardoning), menyalahkan (blambing), memuji (praising), berbelasungkawa (condoling).

4. Komisif, yakni bentuk tuturan yang berfungsi untuk menyatakan janji atau penawaran, misalnya berjanji (promising), bersumpah (vowing), dan menawarkan sesuatu (offering)

5. Deklarasi, yaitu bentuk tuturan yang menghubungkan isi tuturan dengan kenyataan, misalnya berpasrah (resigning), memecat (dismissing), menbaptis (chistening), memberi nama (naming), mengangkat (appointing), mengucilkan (excommicating), dan menghukum (sentencing).

Menurut Yule (2006:93), tindak tutur direktif adalah jenis tindak tutur yang dipakai penutur untuk menyuruh orang lain melakukan sesuatu. Jenis tindak tutur ini menyatakan apa yang menjadi keinginan penutur. Tindak tutur ini meliputi perintah, pesan, permohonan, dan saran. Menurut Bach dan Harnish (1979:47) tindak tutur direktif adalah tindak tutur yang digunakan penutur untuk mengekspresikan maksud penutur yang dijadikan alasan bagi petutur untuk bertindak. Tindak tutur tersebut berupa permintaan, perintah, pertanyaan, dan larangan. Keempatnya dibedakan berdasarkan kekuatan usahanya, tetapi pada dasarnya bertujuan agar petutur melakukan sesuatu untuk penutur (Kreidler, 1998:191). Dapat disimpulkan dari ungkapan-ungkapan di atas bahwa tindak tutur direktif dapat berupa perintah, pesan, permohonan, saran, permintaan, pertanyaan, maupun larangan.

Selain itu, tindak tutur mempunyai beberapa bentuk. Bentuk tindak tutur dalam penelitian ini menggunakan teori 
Wijana. Bentuk tindak tutur yang dimaksud adalah modus kalimat yang dipakai dalam tindak tutur. Menurut Wijana, kalimat berdasarkan modusnya dapat dibedakan menjadi tiga macam, yaitu kalimat deklaratif, kalimat imperatif, dan kaliamat interogatif.

1. Kalimat deklaratif

Kalimat deklaratif berfungsi untuk memberitahukan sesuatu kepada orang lain sehingga tanggapan yang diharapkan berupa perhatian seperti tercemin pada pandangan mata yang menunjukkan adanya perhatian. Kalimat berita mempunyai pola intonasi yang disebut pola intonasi berita.

Kalimat berita di dalamnya tidak ada kata-kata tanya seperti apa, siapa, di mana, mengapa, kata-kata ajakan seperti mari, ayo, kata persilahan silahkan, serta kata larangan jangan. Jadi, penentu jenis kalimat di sini didasarkan pada ciri formal kalimat dan bukan ditentukan oleh tanggapan yang diharapkan dan oleh maknanya.

2. Kalimat imperatif

Kalimat imperatif merupakan kalimat yang mengharapkan tanggapan yang berupa tindakan dari orang yang diajak berbicara dan ditandai dengan intonasi suruh. Berdasarkan strukturnya, kalimat imperatif dapat digolongkan menjadi empat golongan, yaitu kalimat perintah sebenarnya, kalimat larangan, kalimat persilaan, dan kalimat ajakan. Kalimat perintah sebenarnya merupakan kalimat imperatif yang bermaksud perintah, sedangkan kalimat larangan merupakan kalimat imperatif yang bermaksud larangan. kalimat perintah adalah kalimat yang menuntut dilaksanakannya suatu pekerjaan dari pihak yang lebih tinggi kedudukannya kepada pihak yang lebih rendah kedudukannya (Al-Jarim dan Amin, 1999:179). Kalimat perintah dalam bahasa Arab ditandai dengan empat hal, yaitu fi'il amr, lam amr, mashdar pengganti fi'il amr, dan ism fi'il amr. sedangkan kalimat larangan adalah kalimat yang menuntut untuk tidak dilaksanakannya suatu pekerjaan. Kalimat larangan dalam bahasa Arab ditandai dengan fi'il mudhari' yang didahului oleh la nahiyah.

3. Kalimat interogatif

Kalimat interogatif berfungsi menanyakan sesuatu dan ditandai dengan tanda tanya. Menurut Rahardi (2005:77-78), Kalimat interogatif dibagi menjadi dua, yaitu kalimat interogatif total dan kalimat interogatif parsial. Kalimat interogatif total biasanya ditandai dengan adanya kata-kata kah, apa, apakah, bukan, dan bukankah yang hanya memerlukan jawaban $y a$, sudah, tidak, bukan, atau belum. adapun kalimat interogatif parsial biasanya ditandai kata-kata tanya yang memerlukan jawaban penjelasan seperti, apa, siapa, mengapa, kenapa, bagaimana, mana, bilamana, kapan, bila, dan berapa.

Dalam bahasa arab, kalimat interogatif total ditandai dengan adanya kata tanya seperti do dan yang memerlukan jawaban نعم لن ل Pada kata tanya $\mid$, selain memerlukan jawaban نعم dan $\gamma$, kadang dia juga memerlukan jawaban yang berbentuk pilihan. Adapun kalimat interogatif parsial ditandai dengan kata-kata tanya yang memerlukan jawaban ما, من, أين, كيف, ماذ, penjelasan seperti لماذ, أيّ

Kajian pragmatik adalah makna ujaran yang terdapat pada eksternal bahasa. Eksternal bahasa yang dimaksud dalam kajian pragmatik adalah aspekaspek tutur yang meliputi penutur dan petutur, konteks, tujuan tutur, tuturan sebagai tindak tutur dan tuturan sebagai produk tindak verbal. Penutur adalah orang yang mengeluarkan tuturan dan penutur adalah orang yang menjadi sasaran tuturan. Aspek yang berkaitan dengan penutur dan petutur adalah umur, latar belakang sosial, ekonomi, ras, jenis kelamin, tingkat keakraban, dan sebagainya. Konteks adalah suatu 
pengetahuan latar belakang yang samasama dimiliki oleh penutur dan petutur. Konteks tuturan mencakup aspek seting sosial yang melatarbelakangi tuturan yang bersangkutan. Tujuan tuturan adalah maksud penutur mengucapkan sesuatu. Tuturan dalam kajian pragmatik dapat dipahami sebagai bentuk tindak tutur dan dapat dipahami juga sebagai produk tindak tutur.

Hymes (dalam Chaer, 2004:47-49) mengemukakan konsep situasi tutur yang terangkum dalam sebuah akronim SPEAKING yaitu setting (tempat), participant (peserta tutur), ends (tujuan), act of sequence (urutan tutur), keys (cara), instrumenties (media), norms (norma), dan genres (kategori tuturan).

1. S adalah setting, yaitu tempat dan waktu terjadinya pertuturan, termasuk didalamnya kondisi psikologis dan kultural yang menyangkut pertuturan tersebut.

2. $\mathrm{P}$ adalah participant atau peserta tutur, yaitu penutur dan petutur yang merupakan pihak yang terlibat dalam peristiwa tutur

3. E adalah ends, yaitu tujuan yang ingin dicapai dalam suatu situasi tutur.

4. A adalah act of sequence, yaitu urutan tutur yang mengacu pada bentuk dan isi aktual dari apa yang dibicarakan dalam tuturan.

5. $\mathrm{K}$ adalah keys, yaitu cara atau jiwa dari pertuturan yang dilangsungkan. Hal ini meliputi kondisi psikologi seseorang saat bertutur

6. I adalah instrumentalities, yaitu penggunaan kaidah berbahasa dalam pertuturan.

7. $\mathrm{N}$ adalah norm, yaitu norma atau aturan dalam berinteraksi.

8. $\mathrm{G}$ adalah genres, yaitu kategori tuturan yang dapat berbentuk puisi, surat, artikel dan sebagainya.

Penelitian ini merupakan penelitian diskriptif kualitatif. Ada tiga tahapan dalam penulisan penelitian ini, yaitu pengumpulan data, analisis data, dan penyajian hasil analisis data. Pada tahap pengumpulan data, data diperoleh dari hadis dalam buku Asbab Wurud Al-Hadits karya Imam As-Suyuthi dengan menggunakan metode simak dan dilanjutkan dengan menggunakan teknik catat, yakni mencatat hasil penyimakan data pada kartu data (Kesuma, 2007:4445). Data berupa tuturan pada hadis yang mengandung tindak tutur perintah dan larangan. Tuturan-tuturan tersebut dicatat dan ditransliterasikan ke tulisan latin berdasarkan pedoman tranliterasi yang dikeluarkan oleh Menteri Agama dan Menteri Pendidikan dan Kebudayaan Republik Indonesia. Selanjutnya, dilakukan pengklasifikasian data untuk menjawab rumusan masalah yang ada.

Pada tahapan analisis, digunakan metode kontekstual. Penulis berusaha untuk memahami maksud penutur dengan menggunakan kaidah pragmatik yang berorientasi pada konteks sebuah tuturan (Poedjosoedarmo, $t \mathrm{t}$ ). Selanjutnya penulis mengungkap bentuk-bentuk tindak tutur perintah dan larangan.

Setelah analisis data selesai, hasil analisis data akan disajikan dalam bentuk laporan informal (Sudaryanto, 1993:145). Maksud dari penyajian data dalam bentuk laporan informal adalah penyajian data tersebut disampaikan dengan menggunakan kata-kata biasa, yaitu katakata apabila dibaca dengan serta-merta dapat langsung dipahami (Kesuma, 2007:71).

\section{Pembahasan}

Berdasarkan penelitian yang telah dilakukan dapat diketahui bahwa perintah dan larangan Nabi Muhammad merupakan bagian dari tindak tutur direktif yang dalam penyampaiannya memakai tiga modus kalimat, yaitu kalimat imperatif, kalimat deklaratif, dan kalimat interogatif. Jadi, tindak tutur direktif itu tidak hanya disampaikan dengan kalimat imperatif, namun juga dapat disampaikan dengan kalimat deklaratif dan kalimat interogatif. Hal itupun berlaku pada tindak tutur perintah dan larangan yang merupakan bagian dari tindak tutur direktif.

Dilihat dari situasi tutur yang melingkupi tuturan perintah dan larangan Nabi Muhammad, dapat dirumuskan 
karakteristik modus kalimat perintah dan larangan Nabi Muhammad yang berupa kalimat Imperatif, kalimat interogatif, dan kalimat deklaratif.

\section{Kalimat Imperatif}

Kalimat imperatif merupakan kalimat yang mengharapkan tanggapan yang berupa tindakan dari orang yang diajak berbicara dan ditandai dengan intonasi suruh (Ramlan, 1983:37). Menurut Chaer (2009:197), kalimat imperatif ini dapat berupa perintah maupun larangan. Perintah dalam bahasa Arab yang termasuk dalam kalimat imperatif ditandai dengan tiga hal, yaitu fi 'lul-amri, mașdar pengganti fi 'lul-amri, dan ismu fi 'lil-amri, sedangkan larangan dalam bahasa Arab ditandai dengan alfi'lul-mudhari' $u$ yang didahului oleh $l \bar{a}$ an-nahiyah (Al-Jarim dan Amin, 1999:179-184). Dalam penelitian ini ditemukan bahwa kalimat imperatif yang dipakai dalam perintah dan larangan Nabi Muhammad berbentuk fi'lul-amri, ismu fi 'lil-amri, dan lā an-nahiyah.

\section{a. Fi'lul-amri}

Fi'lul-amri adalah verba yang menuntut dilaksanakannya suatu pekerjaan dari pihak yang lebih tinggi kedudukannya kepada pihak yang lebih rendah kedudukannya (Al-Jarim dan Amin, 1999:179). Fi 'lul-amri yang digunakan dalam hadis sebagai penanda perintah dapat dilihat pada hadis-hadis berikut.

$$
\text { امسحوا على الخنّين و الخمار (1) }
$$

Imsah̄u 'alal-khuffaini walkhimāri

'Usaplah bagian atas khuf dan kerudung'. (Hadis ke-7, hal:135)

Konteks: Tuturan Rasulullah kepada pasukan yang diutus untuk sebuah ekspedisi yang mengadu kedinginan ketika berwudu selama menjalankan tugasnya.

Data (1) di atas merupakan tuturan Rasulullah yang berisi perintah kepada pasukan ekspedisi untuk mengusap khuf (sepatu dari kulit) dan penutup kepala ketika berwudhu tanpa harus melepasnya karena hawa dingin yang menyelimuti mereka. Tuturan tersebut dimulai dengan fi 'lul-amri امسحوا imsaḥu 'Usaplah' yang berasal dari verba مسح-يمسح masahayamsahu 'mengusap'. fi 'lul-amri tersebut merupakan bentuk jamak yang ditandai dengan adanya wawu di akhir, sedangkan bentuk tunggalnya adalah امسح imsah 'usaplah'.

Hal yang mendasari munculnya tuturan Rasulullah adalah aduan dari pasukan ekspedisi yang dikirim oleh Rasulullah tentang dingin yang dialami mereka ketika berwudu untuk melaksanakan salat. Wudu merupakan salah satu syarat sahnya salat. Karena salat hukumnya wajib, maka wudu sebelum salat hukumnya juga wajib. Rukun wudu ada lima, yaitu niat, membasuh wajah, mencuci tangan, mengusap sebagian kepala, mencuci kaki, dan tertib. Kesempurnaan wudu sangat penting untuk kesempurnaan salat. Oleh karena itu, Rasulullah menggunakan kalimat imperatif yang berupa perintah dalam tuturannya mengenai wudu, seperti tuturan diatas yang menggunakan kata perintah امسحوا imsahū 'usaplah' untuk perintah mengusap dua khuf sebagai pengganti dua kaki dan mungusap tutup kepala sebagai pengganti sebagian kepala. Dalam bahasa Arab, perintah digunakan oleh orang yang berkedudukan tinggi kepada orang yang berkedudukan lebih rendah. Dalam hal ini, Rasulullah berkedudukan sebagai kepala negara yang memberikan perintah kepada pasukan ekspedisi yang mempunyai kedudukan lebih rendah.

Tuturan Rasulullah di atas merupakan perintah yang hanya dilaksanakan dalam cuaca dingin. Perintah itu adalah keringanan yang diberikan Rasulullah kepada pasukan ekspedisi karena keadaan yang dingin untuk tidak melepas tutup kepala dan dua khuf ketika berwudu dan hanya mengusapnya menggantikan sebagian kepala dan kedua kaki.

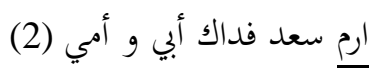


Irmi sa'ad fadāka ab̄̄ wa

ummī

'Panahlah sa'ad, tebusanmu

adalah ayah dan ibuku'.

(Hadis ke-85, hal: 372)

(3)

kepada sa'ad ketika melihat orang-orang musyrik yang membakar amarah muslimin pada perang uhud.

Data (2) di atas merupakan tuturan Rasulullah kepada Sa'ad bin abi waqqash yang berupa perintah untuk memanah orang-orang musyrik yang akan menyerang mereka pada perang uhud. Perintah itu bisa dilihat dari kalimatnya yang menggunakan fi lul-amri ارم irmi 'panahlah' yang berasal dari verba رمى 'ئ 'ramā-yarmī 'memanah'.

Hal yang mendasari tuturan Rasulullah di atas adalah adanya perlakuan dari orang-orang musyrik yang membakar amarah muslimin saat perang Uhud. Tuturan tersebut menggunakan kalimat imperatif berupa perintah dengan kata perintah ارم irmi 'panahlah' karena ketika itu masih dalam keadaan perang yang perlu ketegasan dalam memerintah. Selain itu, bentuk perintah dalam bahasa arab, biasanya digunakan oleh orang yang berkedudukan lebih tinggi kepada orang yang berkedudukan lebih rendah. Posisi Rasulullah dalam perang tersebut merupakan pimpinan perang yang lebih tinggi kedudukannya dibanding sa'ad yang merupakan pasukan perang. Dilihat dari segi umur, Rasulullah pun lebih tua daripada sa'ad.

\section{b. Ismu fi 'lil-amri}

Ismu fi 'lil-amri adalah nomina yang mewakili verba imperatif dalam makna dan penggunaannya (Hamid, 2009:73). Bentuk Ismu fillil-amri mempunyai tingkat kesopanan yang sedikit lebih tinggi dibanding fi 'lul-amri karena berbentuk nomina, tetapi bermakna perintah. Ismu fi 'lil-amri yang digunakan dalam hadis bisa dilihat pada hadis berikut.
(3) إِذَا أُقِيمت الصلاة فلا تأتوها

وأنتم تسعون، وامشوا وعليكم السّكينة

فما أدركتم فصلّوا وما فاتكم فأتمّا

İ̀̄a uqìmatișşalātu fala ta'tūhā wa antum tas 'auna wamsyū wa 'alaikumussakīnata famā adraktum fa șallū wa mā fātakum fa atimmū

'Apabila iqamat salat telah dikumandangkan, maka janganlah kalian mendatanginya dalam keadaan berlari-lari kecil, tetapi datangilah dalam keadaan berjalan dan kalian harus tenang. Seberapa yang kalian dapati kalian laksanakan dan yang tidak kalian dapati sempurnakanlah'. (Hadis ke13, hal:155)

Konteks: Tuturan Rasulullah kepada beberapa orang yang gaduh karena tergesa-gesa untuk mengikuti jamaah bersama Rasulullah.

Pada data (3) di atas terdapat kalimat عليكم السكينة 'alaikumus-sakinata yang menunjukkan kalimat perintah yang berbentuk ismu fi lil-amri. Kalimat عليك

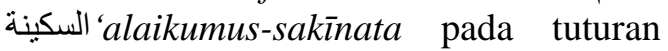
Rasulullah tersebut bermakna الزموا السكينة ilzamus-sakinata 'kalian harus tenang'. Tuturan Rasulullah tersebut berisi perintah untuk bersikap tenang ketika berangkat ke masjid meskipun harus ketinggalan rakaat salat.

Pada tuturan rasulullah di atas, perintah untuk tenang disampaikan dengan bentuk ismu fi lil-amri karena merupakan perintah tambahan sebagai keterangan dari perintah sebelumnya, yaitu امشو imsyū 'berjalanlah'. Tuturan di atas berisi larangan untuk mendatangi salat dengan tergesa-gesa yang diikuti perintah untuk berjalan dengan tenang. Bentuk ismu fi'lil-amri lebih sopan dari fi'lul-amri. 


\section{c. $L \bar{a}$ an-nāhiyah}

$L \bar{a}$ an-nāhiyah adalah huruf yang menjazamkan verba muḍari ‘ yang digunakan untuk melarang. Tingkat kesopanan bentuk Lā an-nāhiyah ini setara dengan tingkat kesopanan bentuk fi 'lulamri. Hadis yang menggunakan bentuk ini dapat dilihat pada data-data berikut.

لا تستنجوا بالروث ولا بالعظام (4)

فإنه زاد إخوانكم من الجنّ

Là tastanjū bir-rausi wa la bil- 'izāmi fa innahu zāda ikhwānikum minal-jinni

'Janganlah kalian beristinjak dengan kotoran binatang atau dengan tulang karena sesungguhnya ia adalah bekal saudara-saudara kalian dari bangsa jin'. (Hadis ke-5, hal: 125)

Konteks: tuturan Rasulullah kepada ibnu mas'ud ketika dia bertanya tentang bekal yang diberikan Rasulullah kepada dua jin yang menemuinya.

Data (4) di atas merupakan tuturan Rasulullah yang berisi larangan beristinjak dengan menggunakan kotoran hewan dan tulang karena kedua benda tersebut adalah bekal bagi bangsa jin. Larangan tersebut dapat dilihat pada susunan تلنتجوا tastanjū 'kalian jangan beristinjak' yang terdiri dari lā an-nāhiyah dan fi 'il mudari " dengan subyek kata ganti أنتم antum 'kalian' yaitu adanya huruf $t a$ ' di awal $f i$ ' $i l$ dan wawul-jama'ah yang diikuti alif pengganti nun di akhir fi 'il. Fi'il muḍāri' tersebut berasal dari verba استنجى-يستنجي istanjā-yastanjū 'beristinjak'.

Hal yang mendasari tuturan Rasulullah di atas adalah adanya pertanyaan dari Ibnu Mas'ud tentang bekal yang diberikan Rasulullah pada dua jin yang menemuinya. Rasulullah memberikan bekal berupa kotoran hewan dan tulang untuk dua jin yang belajar agama dengannya. Karena kotoran hewan dan tulang adalah bekal yang diberikan Rasulullah kepada bangsa jin, maka Rasulullah pun melarang beristinjak dengan kedua benda tersebut. Tuturan di atas menggunakan kalimat imperatif berupa larangan agar beristinjak dengan kotoran hewan dan tulang benar-benar dihindari karena rasulullah sendirilah yang memberikan kedua benda tersebut sebagai bekal bagi bangsa jin.

Seperti halnya bentuk perintah, bentuk larangan juga digunakan oleh orang yang berkedudukan lebih tinggi kepada orang yang berkedudukan lebih rendah. Dalam hal ini, posisi Rasulullah adalah seorang nabi yang berkedudukan lebih tinggi dari Ibnu mas'ud yang mempunyai posisi sebagai umatnya.

لا تقعدوا على القبور (5)

Là taq 'udī 'alal-qubūri

'Janganlah kalian duduk di atas kubur'

(Hadis ke-25, hal: 197)

Konteks: tuturan Rasulullah kepada Umar bin Hazm yang sedang duduk di atas kubur.

Data (5) merupakan tuturan Rasulullah yang berisi larangan duduk di atas kuburan. Larangan tersebut dapat

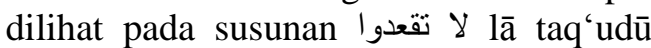
'kalian jangan duduk' yang terdiri dari $l \bar{a}$ an-nāhiyah dan fi'il mudari' dengan subyek kata ganti أنت antum 'kalian' yaitu adanya huruf $t a$ ' di awal fi' $i l$ dan wawuljama'ah yang diikuti alif pengganti nun di akhir fi 'il. Fi 'il muḍāri' tersebut berasal dari kata قعد-يقعد qa 'ada-yaq 'udu 'duduk'.

Hal yang mendasari tuturan Rasulullah di atas adalah tindakan Umar bin Hazm yang duduk di atas kubur,sehingga Rasulullah segera melarangnya. Bentuk larangan dipakai karena Rasulullah ingin larangan itu segera dilakukan. Larangan dapat berfungsi jika penutur lebih tinggi kedudukannya dari mitra tutur. Kedudukan Rasulullah ketika itu adalah sebagai seorang nabi dan umar bin Hazm sebagai umatnya.

\section{Kalimat Interogatif}

Kalimat interogatif berfungsi menanyakan sesuatu dan ditandai dengan tanda tanya. Menurut Rahardi (2005:7778), Kalimat interogatif dibagi menjadi 
dua, yaitu kalimat interogatif total dan kalimat interogatif parsial. Kalimat interogatif total disebut juga dengan kalimat tanya ya-tidak dan biasanya ditandai dengan adanya kata-kata kah, apa, apakah, bukan, dan bukankah yang hanya memerlukan jawaban $y a$, sudah, tidak, bukan, atau belum. adapun kalimat interogatif parsial yang biasa disebut kalimat tanya informasi dan biasanya ditandai kata-kata tanya yang memerlukan jawaban penjelasan seperti, apa, siapa, mengapa, kenapa, bagaimana, mana, bilamana, kapan, bila, dan berapa.

Dalam bahasa Arab, kalimat interogatif ditandai dengan adanya kata tanya seperti su dan I yang memerlukan

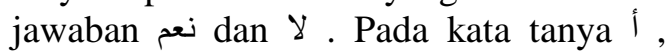
selain memerlukan jawaban نعم ل ل kadang dia juga memerlukan jawaban yang berbentuk pilihan. Adapun kalimat interogatif parsial ditandai dengan katakata tanya yang memerlukan jawaban ما, من, أين, كيف, ماذ, لماذ, penjelasan seperti .

\section{a. Kalimat Interogatif Total}

Kalimat interogatif

dimaksudkan untuk menanyakan keseluruhan informasi yang terdapat dalam pertanyaan. Kalimat interogatif total itu menanyakan tentang kesetujuan dan ketidaksetujuan mitra tutur. Dalam bahasa Arab, kalimat interogatif total ditandai dengan adanya kata tanya o hal 'apakah' dan I a 'apakah'. Kalimat Interogatif total dalam hadis yang mempunyai maksud untuk memerintah adalah sebagai berikut.

أرأيتكم ليلتكم هذه؟ فإنّ على (6)

رأس مائة سنة منها لا يبقى تمّن هو لئم

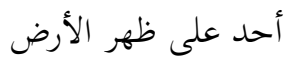

Ara'aitakum lailatakum

hażihi? Fa inna 'ala ra'si

mi'ati sanatin minhā lā

yabqā mimman huwa 'alā

zahril-arḍi ahadun

'Apakah kalian tidak

memperhatikan malam kalian

ini? Sesungguhnya pada

penghujung seratus tahun dari malam ini, tidak ada seorang pun yang hidup di muka bumi (saat ini) yang masih tersisa'. (Hadis ke-59, hal: 309)

Konteks: Tuturan Rasulullah kepada para sahabatnya setelah salat isya' sebulan sebelum Rasulullah wafat.

Data (6) merupakan tuturan Rasulullah kepada sahabat-sahabatnya yang berisi perintah untuk memperhatikan malam mereka ketika itu. Perintah tersebut disampaikan dengan kalimat interogatif yang ditandai dengan kata tanya 1 a 'apakah'. Kalimat interogatif itu tidak membutuhkan jawaban نعa 'am 'ya' atau $\vee \quad l \bar{a}$ 'tidak' seperti halnya jawaban untuk kata tanya dalam kalimat interogatif tersebut, tetapi membutuhkan tindakan dari mitra tutur untuk memperhatikan masa hidupnya yang tidak lebih dari seabad.

Tuturan itu disampaikan setelah shalat isya' sebulan sebelum Rasulullah wafat. Tuturan itu berbentuk interogatif dengan maksud perintah untuk memperhatikan malam mereka karena generasi mereka, generasi para sahabat, akan berakhir seratus tahun kemudian setelah malam itu. Tuturan itu disampaikan dalam keadaan yang tenang dengan tujuan agar pada malam itu, mereka dapat merenungkan hal-hal yang akan dilakukan ke depannya nanti. Tuturan tersebut merupakan pandangan seorang nabi yang sudah diberitahu sekilas tentang masa depan sehingga dapat mengetahui bahwa generasi sahabat akan berakhir seratus tahun kemudian. Pandangan itu pun disampaikan kepada para sahabatnya dengan didahului dengan perintah untuk memperhatikan malam itu.

أما يخشى أحدكم أو لا يخشى (7)

$$
\begin{aligned}
& \text { أحدكم إذا رفع رأسه قبل الإمام أن } \\
& \text { الله يجعل الله رأسه رأس حمار ، أو يجعل راسله } \\
& \text { صورته صورة حمار } \\
& \text { A mā yakhsya ahadukum aw } \\
& \text { lā yakhsya ahadukum iża } \\
& \text { rafa'a ra'sahu qablal-imāmi }
\end{aligned}
$$


an yaj'alallahu ra'sahu ra'sa himārin aw yaj'alallahu șūratahu șūrata himārin

'Tidakkah takut salah seorang diantara kalian atau tidak takutkah salah seorang diantara kalian apabila ia mengangkat kepalanya sebelum imam, Allah akan menjadikan kepalanya seperti kepala keledai atau Allah menjadikan bentuknya seperti bentuk keledai'. (Hadis ke-11, hal: 152)

Konteks: Tuturan Rasulullah kepada pengikutnya yang salat bersamanya. Ketika itu, ada seseorang yang mendahului Rasulullah ketika rukuk dan bangkit dari rukuk.

Data (7) di atas adalah tuturan Rasulullah kepada sahabat-sahabatnya yang berisi larangan mendahului imam ketika bangkit dari rukuk. Larangan ini disampaikan dengan kalimat interogatif yang ditandai dengan kata tanya i $a$ 'apakah'. Larangan itu disampaikan karena ada salah satu sahabat yang mendahului rasulullah ketika bangkit dari rukuk. Kalimat interogatif itu tidak membutuhkan jawaban نعa 'am 'ya' atau $\vee ~ l \bar{a}$ 'tidak' seperti halnya jawaban dari kata tanya dalam kalimat interogatif tersebut, tetapi membutuhkan tindakan dari mitra tutur untuk tidak mendahului imam.

Tuturan Rasulullah di atas disampaikan setelah salat berjamaah, karena ada seorang laki-laki yang rukuk dan bangkit dari rukuk mendahului Rasulullah hanya untuk menguji pengetahuan Rasulullah tentang perbuatannya itu. Rasulullah melarang laki-laki itu dan juga yang lainnya untuk tidak mendahului imam dalam rukuk dan bangkit dari rukuk karena Allah akan menjadikan kepala atau bentuknya seperti kepala atau bentuk keledai. Tuturan itu disampaikan dengan kalimat interogatif untuk sebuah larangan agar tidak menyinggung laki-laki tersebut. Objek dari tuturan tersebut pun diarahkan kepada jamaah yang lain dan tidak langsung kepada laki-laki tersebut agar yang lain dapat mengambil pelajaran dari kejadian itu.

\section{b. Kalimat Interogatif Parsial}

Kalimat interogatif parsial adalah kalimat interogatif yang dimaksudkan untuk menanyakan sebagian informasi yang terkandung di dalam pertanyaan. Kalimat interogatif ini, biasanya menggunakan kata tanya yang jenis dan macamnya ditentukan berdasarkan sifat objek yang dimaksudkan dalam kalimat tersebut. Kalimat interogatif dalam hadis yang mengandung maksud perintah maupun larangan dapat dilihat pada tuturan berikut.

$$
\begin{aligned}
& \text { ما لي أراكم تتهافتون في الكذب (8) } \\
& \text { كما تتهافت الفراث في النار، ألا أنّ كان } \\
& \text { كل كذب مكتوب على ابن آدم إلاّ } \\
& \text { في ثلاث: كذب الرجل امرأته ليرضيها } \\
& \text { و كذب الرجل للحرب فإنّ الحرب } \\
& \text { خذعة و كذب الرجل في الإصلاح } \\
& \text { بين الرجلين }
\end{aligned}
$$

Mā lì arākum tatahāfatūna fil-każibi kamā tatahāfatulfarāsyu fin-nāri. alā anna kulla kizibin maktūbun 'alā ibni àdama illā fi salāsin: każabar-rajulu imra'atahu liyurḍīhā wa każabar-rajulu lil-harbi fa innal-harba khuż'atun wa każabar-rajulu fil-iṣlāhi bainar-rajulaini 'mengapa aku melihat kalian mengikuti kebohongan seperti anai-anai berterbangan pada api. Ketahuilah, setiap kebohongan tercatat atas nama anak adam kecuali dalam tiga perkara: bohongnya seorang laki-laki terhadap istrinya untuk mengambil hatinya, bohongnya laki-laki dalam perang, karena sesungguhnya perang adalah tipu daya, dan 
bohongnya laki-laki untuk mendamaikan dua orang'

(Hadis ke-98, hal: 406)

Konteks: Tuturan Rasulullah

kepada pasukan ekspedisi

yang dikirimnya setelah

mendapat laporan dari

seorang laki-laki yang

dizalimi mereka dengan

menolak kambing yang

diberikan mereka karena

dianggap kurus, kemudian

memaksa untuk

menggunakan kemah yang

merupakan kandang kambing

dan mengeluarkan kambing

itu. Mereka mengatakan

bahwa laporan itu bohong.

Kemudian Rasulullah

bertanya kepada salah

seorang diantara pasukan

ekspedisi yang dilihat ada

kebaikan darinya. Orang

itupun berkata bahwa laporan

itu benar.

Data (8) di atas adalah tuturan

Rasulullah kepada pasukan ekspedisi yang berisi larangan untuk mengikuti kebohongan. Larangan itu disampaikan dengan kalimat interogatif yang ditandai dengan kata tanya ما لي $m \bar{a} \bar{l}$ 'mengapa'. Kalimat interogatif tersebut tidak membutuhkan keterangan sebab mereka mengikuti kebohongan seperti halnya jawaban dari kata tanya dalam kalimat interogatif itu, tetapi membutuhkan tindakan dari mitra tutur untuk tidak mengikuti kebohongan.

Tuturan Rasulullah tersebut ditujukan kepada pasukan ekspedisi yang melakukan kebohongan mengenai hal yang telah mereka lakukan, yaitu mendzalimi seseorang dengan menolak kambing yang diberikan mereka karena dianggap kurus, kemudian memaksa untuk menggunakan kemah yang merupakan kandang kambing dan mengeluarkan kambing itu. Sehingga Rasulullah memperingatkan mereka tentang jeleknya berbohong dengan membatasi jenis kebohongan yang diperbolehkan, yang hanya ada dalam tiga kondisi saja, yaitu bohongnya seorang laki-laki terhadap istrinya untuk mengambil hatinya, bohongnya laki-laki dalam perang, dan bohongnya laki-laki untuk mendamaikan dua orang. Dalam kata lain, selain tiga kondisi yang disebutkan nabi tersebut, maka berbohong adalah perbuatan yang dilarang.

Kalimat interogatif yang digunakan Rasulullah untuk sebuah perintah kepada pasukan ekspedisi merupakan bentuk kesantunan Rasulullah yang ditunjukkan kepada pasukan ekspedisi yang dikirimnya untuk menghormati tugas yang mereka emban. Kesantunan lain yang juga tampak di dalam hadis tersebut adalah penggunaan perumpamaan, yaitu menyamakan rombongan tersebut dengan segerombolan laron, dan kebohongan dengan api yang dapat membakar laron yang mengikutinya.

\section{Kalimat Deklaratif}

Kalimat deklaratif berfungsi untuk memberitahukan sesuatu kepada orang lain sehingga tanggapan yang diharapkan berupa perhatian seperti tercemin pada pandangan mata yang menunjukkan adanya perhatian. Kalimat deklaratif mempunyai pola intonasi yang disebut pola intonasi berita. Pada kalimat deklaratif, tidak ada kata-kata tanya seperti apa, siapa, di mana, mengapa, kata-kata ajakan seperti mari, ayo, kata persilahan silahkan, serta kata larangan jangan. Jadi, penentu jenis kalimat di sini didasarkan pada ciri formal bentuk kalimat dan bukan ditentukan oleh tanggapan yang diharapkan dan oleh maknanya. Menurut Hasyimi (1999:66), bentuk kalimat deklaratif dalam bahasa Arab dibagi menjadi dua, yaitu kalimat verba dan kalimat nomina.

\section{a. Kalimat Verba}

Kalimat verba adalah kalimat yang didahului oleh verba (Gani, 2010:203). Menurut Gulayaini (2013:691), kalimat verba merupakan kalimat yang tersusun dari al-fi' lu dan al-fā'il. Kalimat verba deklaratif yang bermaksud perintah dan larangan dalam hadis dapat dilihat pada tuturan-tuturan berikut. 
أفطر الحاجم و المحجوم (9)

Aftaral-hājimu wal-mahjūmu

'Telah berbuka puasa orang yang membekam dan dibekam'. (Hadis ke-30, hal: 216)

Konteks: tuturan Rasulullah kepada Syaddad bin Aus yang saat itu bersama Rasulullah ketika melewati tukang bekam yang sedang membekam sambil bergunjing.

Data (9) di atas adalah tuturan Rasulullah kepada syaddad bin Aus yang berisi larangan untuk menggunjing ketika berpuasa. Larangan tersebut disampaikan dengan kalimat deklaratif yang ditandai dengan ketiadaan kata perintah dan kata tanya. Kalimat deklaratif tersebut berupa kalimat verba karena didahului oleh verba أفطر aftara 'berbuka puasa' dan tersusun dari al-fi'lu dan al-fā'ilu. Al-fi'lu dalam kalimat tersebut adalah أفطر afțara 'berbuka puasa', sedangkan al-fā'ilunya adalah الحاجم al-hājimu 'yang membekam'.

Tuturan di atas adalah ditujukan kepada syaddad bin aus, sahabat Rasulullah, agar dia tidak bergunjing ketika puasa. Tuturan itu keluar ketika melewati tukang bekam yang membekam pasiennya sambil bergunjing. Hal itu terjadi pada bulan Ramadan.

\section{b. Kalimat Nomina}

Kalimat nomina adalah kalimat yang didahului oleh nomina (Ghani, 2010:203). Menurut Gulayaini (2013: 691), kalimat nomina merupakan kalimat yang tersusun dari mubtada' dan khabar. Kalimat nomina yang bermaksud perintah dan larangan pada hadis dapat dilihat pada tuturan-tuturan berikut.

اليد العلي خير من اليد السفلى (10)

Al-yadul-'ulya khairun minal-yadis-suflā

'Tangan di atas lebih baik dari tangan di bawah'

(Hadis ke-61, hal: 315)

Konteks: Tuturan Rasulullah kepada Hakim Ibnu Hizam ketika dia meminta sedekah

ketiga kalinya kepada

Rasulullah dan selalu diberi.

Data (10) di atas adalah tuturan Rasulullah kepada kepada Hakim Ibn Hizam yang berisi larangan untuk meminta-minta. Larangan tersebut disampaikan dengan kalimat deklaratif yang ditandai dengan ketiadaan kata perintah maupun kata tanya. Kalimat deklaratif yang dipakai berupa kalimat nomina karena didahului oleh nomina yaitu اليد al-yadu 'tangan' dan terdiri dari mubtada' dan khabar. Mubtada' pada kalimat itu adalah اليد al-yadu 'tangan' yang disifati dengan kata العلي al- 'ulyà 'di خير atas', sedangkan khabarnya adalah khoirun 'lebih baik'.

Tuturan di atas ditujukan kepada Hakim Ibn Hizam. Dia meminta sedekah kepada Rasulullah,lalu Rasulullah memberinya. Hal itu dilakukannya sampai tiga kali sehingga Rasulullah pun melarangnya untuk meminta sedekah lagi dengan memberitahu bahwa tangan di atas lebih baik dari tangan di bawah yang artinya memberi lebih baik dari meminta.

\section{Kesimpulan}

Hadis merupakan pedoman hidup umat Islam setelah al-Qur'an. Hadis merupakan perkataan, perbuatan, dan ketetapan Nabi Muhammad yang harus dipahami secara bahasa dan dikaitkan dengan konteks yang melingkupinya sehingga mendapatkan pemahaman yang benar. Selain itu, dalam mengungkapkan kata-katanya, Nabi Muhammad juga menggunakan strategi tertentu agar perkataannya dapat diterima dengan baik oleh mitra tuturnya. Berdasarkan hasil penelitian dan pembahasan tentang modus tindak tutur perintah dan larangan Nabi Muhammad dalam hadis ini, dapat diketahui bahwa tindak tutur perintah dan larangan dalam hadis mempunyai beberapa modus kalimat, yaitu: a) Kalimat deklaratif, dengan bentuk kalimat verba dan kalimat nomina, b) Kalimat Imperatif, dengan bentuk fi 'lul-amri, ismu fi 'lil-amri, dan lā an-nahiyah c) Kalimat interogatif yang ditandai dengan pemakaian kata "“" "مَّ". 


\section{Daftar Pustaka}

Austin, J.L. 1962. How to Do Things with Words. Oxford: Oxford University Press.

Bach, Kent dan Robert M. Harnish. 1979. Linguistic Communication and speech act. London: The MIT Press.

Chaer, Abdul. 2009. Sintaksis Bahasa Indonesia: Pendekatan-Proses. Jakarta: Penerbit Rineka Cipta

Ghani, Aiman Amin Abdul. 2010. AnNahwu Al-Kafi. Dar AtTaufiqiyyah Li At-Turats: Kairo

Gulayaini, Mushthafa. 2010. Jāmi'ul Durūs al-'Arabiyah. Cairo : Darussalam

Hamid. Muhyidin Abdul. 2009. Audahu Al-Masaliki Ilā Alfiyati Ibni Māliki Jilid 4. Kairo: Dar AtTalā'i'i Lin-Nasyri Wa AtTaiz̄̄' $i$

Al-Jarim, Ali dan Musthafa Amin. 1999. Al-Balāgah Al-Wädihah. Kairo: Darul Ma'arif.

Jazuli, Ahmad, 2015. Tindak Tutur Perintah dan Larangan dalam Hadis. Yogyakarta: Universitas Gadjah Mada.

Kesuma, Tri Mastoyo Jati. 2007. Pengantar Metode Penelitian Bahasa. Yogyakarta: Carasvati Book.

Kreidler, Charles W. 1998. Introduction English Semantic. London: Routledge.
Levinson, Stephen C. 1991. Pragmatics. Cambridge: Cambridge University Press.

Parker, Frank. 1986. Linguistics for Non Linguist. London: Taylor and Francis, Ltd.

Poedjosoedarmo, Soepomo. tt. Penentuan Metode Penelitian (Naskah).

Purwo, Bambang Kaswanti. 1990. Pragmatik dan Pengajaran Bahasa. Yogyakarta: Kanisius.

Rahardi, Kunjana. 2005. Pragmatik: Kesantunan Imperatif Bahasa Indonesia. Jakarta: Penerbit Erlangga.

Rohmadi, Muhammad. 2010. Pragmatik: Teori dan Analisis. Surakarta: Yuma Pustaka.

Searle, J.R. 1969. Speech Act: An Essay in the Philosophy Of Language. Cambridge: Cambridge University Press.

Sudaryanto. 1993. Metode dan Teknik Analisis Bahasa. Yogyakarta: Duta Wacana Press.

As-Suyuthi, Imam Jalaluddin. 2009. Asbab Wurud Al-Hadits. Jakarta: Pustaka As-Sunah.

Wijana, I Dewa Putu. 1996. DasarDasar Pragmatik. Yogyakarta: Andi Pustaka Pelajar.

2010. Analisis Wacana Pragmatik: Kajian Teori dan Analisis. Surakarta: Yuma Pustaka

Yule, George. 2006. Pragmatik. Yogyakarta: Pustaka Pelajar. 